\title{
COMMUNITY PERCEPTIONS OF BIOMEDICAL HEALTH CARE IN A RURAL AREA IN THE NORTHERN PROVINCE SOUTH AFRICA
}

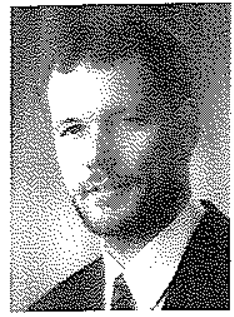

\author{
Prof. Karl Peltzer \\ Dept. of Psychology \\ University of the North
}

\begin{abstract}
The success of strategies to revitalise primary health care services such as those advocated by the Bamako Initiative requires a response adapted to the expectations of the population, especially in terms of quality. The goal of this study was to investigate community perceptions of availability, accessibility, acceptability and affordability of biomedical health care services in a rural area of the Northern Province in South Africa. A multi-stage cluster sampling method was used to ensure random inclusion of respondents. The sample consisted of $85 \mathrm{men}(49 \%)$ and 89 women $(51 \%)$, the age ranged from 18 to 88 years with a mean of 32.8 $(S D=13.9)$. Participants were interviewed face-to-face with a structured questionnaire on demographic and health facility data, health status, accessibility, affordability, availability and quality of health care, and a Health Beliefs Questionnaire. Results indicate a low acceptability of biomedical health care: $78 \%$ felt that the medical services are poor: There was a significant relationship between not being member of a medical scheme, poorer health status and availability of health care services. The poorer health status was also significantly related with acceptability of health services. Illness attributes, employment status, gender and health beliefs were not related to any of the health services parameters. It is suggested that primary health care policy takes cognisance of the existing differences like that of acceptability and affordability in attitudes toward biomedical health care.
\end{abstract}

\section{OPSOMMING}

Die sukses van strategie om primêre gesondheidsorgdienste soos die wat deur die Bamako Inisiatief voorgestaan word, hang af van 'n reaksie wat rekening hou met die verwagting van die gemeenskap, spesifiek ten opsigte van kwaliteit. Die doel van die navorsing was on die persepsies van die gemeenskap na te vors ten opsigte van beskikbaarheid, toeganklikheid, en bekostigbaarheid van biomediese gesondheidsorgdienste in ' $n$ plattelandse gebied in die Noordelike Provinsie in Suid-Afrika. Daar is van bondelssteekproeftrekking in fases gebruik gemaak om ewekansigheid te verseker. Die steekproef het bestaan uit 85 mans $(49 \%)$ en 89 vroue (51\%) met 'n verspreiding van 18 tot 88 jaar met 'n gemiddelde ouderdom van van 32.8 (standaarafwyking van 13.9). Daar is gebruik gemaak van 'n gestruktureerde vraelys waarvan die inligting deur een tot een onderhoude bekom is. Inligting oor die volgende faktore is bekom: demografiese en gesondheidsorginligting, gesondheidstatus, toeganklikheid, bekostigbaarheid, beskikbaarheid, kwaliteit van die gesondheidsorg, en 'n vraelys oor menings oor gesondheid. Die resultate toon 'n lae aanvaarbaarheid van biomediese gesondheidsorg; 78\% het aangetoon dat die mediese dienste swak is. Daar was 'n betekenisvolle verhouding tussen faktore soos: om nie lid van 'n mediese fonds te wees nie, swakker gesondheid en beskikbaarheid van gesondheidsdienste. Swakker gesondheid korreleer ook met die aanvaarbaarheid van gesondheidsdienste. Die volgende faktore toon geen verband met gesondheidsorg nie: siektes, geslag, gelowe oor gesondheid en werkloosheid al dan nie. Die gevolgtrekking waartoe die studie kom is dat die beleid ten opsigte van primêre gesondheidsorg kennis moet neem van die bestaande verskille soos die aanvaarbaarheid en bekostigbaarheid in die houdings ten opsigte van biomediese gesondheidsorgdienste.

\section{INTRODUCTION}

Medical facilities in the Northern Province are inadequate considering the size of the population. In 1992 there were 4.7 hospital beds available per 1000 people. The national average is 5.1 beds, and 6.5 beds per 1000 people in Gauteng. The Northern Province is in dire need of medical officials, having only 796 practitioners for 5.3 million people in 1992 or 0.2 per 1000 people. The national average is 0.6 doctors per 1000 people. Another important determinant of health status is the availability of health facilities. This includes accessibility and quality of service. In general, health facilities are more readily available in urban areas. However, these facilities have a strong curative bias, and many are situated too far from where the poor people live. Rural people not only have limited facilities, but access to these facilities is also restricted. People living further than $5 \mathrm{~km}$ from medical facilities constitute $44.4 \%$ of the population, while $11.3 \%$ belong to a medical aid benefit fund in the Northern Province. Health status is not only determined by access to facilities for mainly curative purposes, but also by other factors which prevent the onset of illness and malnutrition. Income is seemingly the most important factor in this regard, as there is a strong correlation between income levels and health status (Development Bank of Southern Africa, 1998:53).

The health care needs in rural South African environments are mainly addressed by traditional or faith healers and primary health care clinics run by nurses. In the light of the absence of medical doctors in 
near reach this study reflects on the attitudes towards availability, accessibility, acceptability and affordability of biomedical health care services in a rural area of the Northern Province in South Africa. Little attention has been paid to the quality of primary health care services in developing countries. This can be explained by the priority that has long been placed on improving availability of services in contexts where there have been enormous needs that have rarely been met. The evaluation of the quality perceived by the public is justified in the desire to meet users expectations, thereby contributing to the process of democratisation of health care services (Haddad, Fournier, Machouf \& Yatara, 1998:382).

During the Reconstruction and Development era, in South Africa, very little literature is found on the provision of Primary Care Services (Thipanyana \& Mavundla, 1998:23).

Van Vuuren and Botes (1994:2) found among a culturally diverse population in an urban area in South Africa (greater Bloemfontein) that variables such as population group, age and employment status influence their attitudes towards professional health care. They further emphasise the importance of bringing these issues to the attention of the health care policy makers. Miralles and Kimberlin (1998:345) found among elderly from different socio-economic backgrounds in Rio de Janeiro that residents of the low-income community reported less availability of services, more difficulties with affordability and greater acceptability of pharmacy services than their high-income community counterparts. Heap and Ramphele (1991:117) studied health care strategies among residents of South African hostels indicating that choice of therapy depends on cost, availability, and experience with various healing systems. Haddad, Fournier, Machouf et al. (1998:381) studied community perceptions of primary health care services in Guinea. From a taxonomy of perceived quality the following categories were identified: (1) technical competence of the health care personnel, (2) interpersonal relations between patients and care providers, (3) availability and adequacy of resources and services, (4) accessibility and (5) effectiveness of care. On Tanzanian women's views of the quality of Primary Health Care Services, Atkinson and Ngenda (1996:3ff.) found 6 dimensions: (1) conduct of health staff, (2) technical care, (3) convenience of the health facility, (4) organisation of the health care, (5) drugs and (6) structural aspects. In addition, the role of worldviews in health care systems has been acknowledged (Craffert, 1997:1; Hildebrandt, 1997:155; Pillay, 1996:4).

Considering the above components and concepts of care and quality of health care, the purpose of this study is to examine the concepts of availability, accessibility, acceptability, and affordability as applied to biomedical health care in a rural South African community (Anyinam, 1987:803).

It is hypothesized that illness attributes (medical, supernatural and psychosocial), socio-economic status, subjective health status, member of medical scheme, and distance to health facilities have an impact on the attitude towards biomedical health care in terms of availability, accessibility, affordability and acceptability. On the basis of these parameters questionnaires were chosen, which were previously used on South African populations, to measure "quality of health care" and "health beliefs".

\section{METHODS}

\section{Sample and procedure}

The sample consisted of 85 men (49\%) and 89 women $(51 \%)$, the age ranged from 18 to 88 years with a mean of $32.8(\mathrm{SD}=13.9)$. One hundred and sixty-two $(95 \%)$ were Northern Sotho and the remaining $12(5 \%)$ belonged to different ethnic groups. Ninety-six (40\%) were married , 83 single (48\%), 15 widowed $(9 \%)$, and 7 divorced (4\%). Most (72\%) including "housewives" were categorised as unemployed and $49(28 \%)$ employed. Sixty-seven $(38.5 \%)$ belonged to the Zion Christian Church (ZCC), 18 Roman Catholic (10\%), 14 African belief $(8 \%)$, and the remaining $75(43 \%)$ belonged to 15 different religious denominations.

A multistage cluster sampling method was used to ensure random inclusion of respondents from the GaMolepo area, which is $60 \mathrm{kms}$ southeast of Pietersburg (cf. Van Vuuren \& Botes, 1994:3). In the first phase villages from the GaMolepo area were randomly selected; in the second phase dwelling units representing households were randomly selected, and the third phase involved the identification of a single respondent per residential unit.

Participants were interviewed face-to-face with a structured questionnaire by a trained African interviewer (with a matric qualification and fluency in English and Northern Sotho) in the language of the participants.

\section{Inventory}

The structured questionnaire consisted of 13 items on demographic and health facility data, 1 item on health status, and 17 items on Quality of Health Care (cf. Van Vuuren \& Botes, 1994:3f.), and a 30-item Health Belief Questionnaire (HBQ) (Pillay, 1996:5). The questionnaire was tested with 10 participants, which did not form part of the final sample in order to ensure validity and reliability.

The quality of health care questionnaire consisted of 
four components: accessibility ( 3 items), affordability ( 5 items), availability ( 3 items), and acceptability (6 items). Answers were rated on a five-point Likert scale from 1 =agree fully to 5 =disagree strongly. The Cronbach alpha as well as the split-half reliability coefficient for the quality of health care questionnaire was .7 for this sample.

The HBQ consisted of 20 items etiological beliefs ( 10 external ancestral/evil, 4 medical, 4 self-blame, and 2 physical weakness or body malfunction), 8 items treatment beliefs ( 4 self-medication, home treatment, 2 medical, 1 prayer, 1 holistic treatment), 2 item preventive belief ( 1 self-care, 1 hygiene). The items can also be divided into 8 items for medical attribution, 12 items for supernatural attribution, and 10 for psychosocial attributions. The HBQ is designed to ascertain health and illness beliefs. It requires the respondents to rate on a four-point Likert scale whether they agree, sometimes agree, disagree, or were not sure about the statement presented. The Cronbach alpha and split-half reliability coefficient for the HBQ was .81 and .85 , respectively, for this sample.

\section{RESULTS}

Most (137) (79\%) were not members of a medical aid scheme, whereas $37(21 \%)$ were. From those who were employed the mean monthly income was R 1844 $(S D=1354)$, range $R 300$ to $R 5600$. The nearest clinic was estimated at a mean of $4.8 \mathrm{~km}(\mathrm{SD}=5.2)$, range 1 to $29 \mathrm{~km}$, and the nearest clinic in minutes: mean 38 minutes ( $\mathrm{SD}=22.3)$, range 4 to 120 minutes. The nearest doctor was estimated at a mean of $20.3 \mathrm{~km}(\mathrm{SD}=8)$, and the nearest doctor in minutes: mean 55 minutes $(\mathrm{SD}=29)$. The nearest hospital was estimated at a mean of $24.8 \mathrm{~km}(\mathrm{SD}=13.3)$, and the nearest hospital in minutes: mean $75(\mathrm{SD}=46)$.

Most participants $(33 \%)$ rated their health with excellent, whereas $20 \%$ rated it as good, $24 \%$ reasonable, and $21 \%$ as poor.

Table 1 indicates the availability, accessibility, affordability and acceptability of health care in percent. Regarding availability $84 \%$ of the participants felt that there are not enough family doctors in their area. On the other hand almost one-third (31\%) tended to use medical services just because it is available. More than one-third of the participants stated problems with the

Table 1: Availability, accessability, affordability and acceptability of health care in percent. $(N=174)$

\begin{tabular}{|c|c|c|c|}
\hline Availability & AF/A & $U$ & D/DS \\
\hline 1. I don't think that there are enough family doctors (GP's) in our area. & 84 & 3 & 14 \\
\hline 12. People tend to use medical service just because it is avallable & 31 & 18 & 51 \\
\hline 15. There are medical services I can use even though I can't pay for it & 30 & 22 & 48 \\
\hline \multicolumn{4}{|l|}{ Accessibility } \\
\hline 4. The doctor will only see me during consultation hours & 37 & 15 & 48 \\
\hline 5. Al clinics should be open after business hours as well & 43 & 19 & 38 \\
\hline 10. I can never see the doctor without an appointment & 38 & 20 & 42 \\
\hline \multicolumn{4}{|l|}{ Affordability } \\
\hline 2. People should receive free medical care in the hospital & 63 & 12 & 25 \\
\hline $\begin{array}{l}\text { 6. Because municipal clinics are free, I'd rather go to one of them than to a } \\
\text { clinic that I would pay }\end{array}$ & 56 & 11 & 33 \\
\hline 11. Medical services are not really expensive at all & 34 & 17 & 49 \\
\hline 13. Doctors are not expensive considering the type of service they give & 38 & 27 & 35 \\
\hline 14. Medical expenses have become so expensive that I cannot afford it & 37 & 20 & 43 \\
\hline \multicolumn{4}{|l|}{ Acceptability } \\
\hline $\begin{array}{l}\text { 3. Generally speaking, clinic nurses should refer their patients for test more } \\
\text { often }\end{array}$ & 71 & 20 & 9 \\
\hline 7. When I am admitted to hospital, I become just another "case" or number & 37 & 28 & 35 \\
\hline 8. The quality of medical services in GaMolepo is excellent & 13 & 9 & 78 \\
\hline $\begin{array}{l}\text { 9. Generally speaking, murses are so busy writing reports and filling in forms } \\
\text { that they can't look after their patients properly }\end{array}$ & 51 & 16 & 33 \\
\hline 16 "Home remedies" are often better than medicines doctors prescribe & 25 & 25 & 50 \\
\hline 17 "Over-the-counfer drugs are often better than medicines doctors prescribe & 26 & 15 & 59 \\
\hline
\end{tabular}


accessibility of biomedical health care, like $43 \%$ felt that clinics should remain open after business hours and $38 \%$ that one can never see the doctor without an appointment. About two-third (63\%) of the participants felt that one should receive free medical care in the hospital and $56 \%$ would rather go to a clinic where medical treatment is free. On the one hand almost half $(49 \%)$ agreed that medical services are expensive and have even become more expensive $(43 \%)$ but on the other hand $38 \%$ agreed that doctors are not expensive considering the type of service they give. The acceptability of health care in the GaMolepo area was generally considered poor: $78 \%$ felt that the medical services are poor, $71 \%$ felt clinic nurses should refer their patients for test more often and 51\% agreed that nurses are so busy that they can not look after their patients properly. There was high trust in biomedical health care since $59 \%$ noted that over-the-counter drugs and $50 \%$ that home remedies are not better than medicines doctors prescribe.

Table 2 shows the correlation between independent variables and attitudes towards health care.

There was a significant relationship between not being a member of a medical scheme, poorer health status and availability of health care services. The poorer health status was also significantly related with acceptability of health services. Employment status and gender was not related to any of the health services parameters.
There seems to be a significant association between increasing age, member of a medical scheme, poorer health status and the statement that there are insufficient family doctors (GPs) in the area. The other two health indicators (free hospital care and improved referral by clinic nurses for tests) Were not related to health status and medical scheme membership.

Table 3 indicates health beliefs by differential attributes.

Highest rates for health attributions were found for: (1) visiting a doctor for regular check-ups can prevent a person from getting sick; (2) people go to doctors when they are seriously ill; (3) people get sick because they do not eat proper foods or do not keep themselves clean; (4) illness is caused by infection; and (5) people inherit illness from their parents. Interesting is that participants agreed to a large extent that older people play an important role in terms of knowledge about illness, advise and treatment. The most important supernatural attribute was doctors can make the illness better but they cannot treat the cause. In addition, people should pray and observe rituals to prevent and treat illness. Across the three categories of health attributes medical was most important, followed by psychosocial and supernatural in that order.

The three health belief attributes (medical, supernatural, and psychosocial) were correlated (using

Table 2 : Correlations between independent variables (A) and attitudes towards heath care (B)

(A)

\begin{tabular}{|l|l|l|l|l|l|l|l|l|}
\hline \multirow{2}{*}{$\begin{array}{l}\text { Independent } \\
\text { variable }\end{array}$} & \multicolumn{2}{|l|}{ Availability } & \multicolumn{2}{l|}{ Accessibility } & \multicolumn{2}{l|}{ Affordability } & \multicolumn{2}{l|}{ Acceptability } \\
\cline { 2 - 9 } & $\mathrm{F}$ & $\mathrm{P}$ & $\mathrm{F}$ & $\mathrm{P}$ & $\mathrm{F}$ & $\mathrm{P}$ & $\mathrm{F}$ & $\mathrm{P}$ \\
\hline $\begin{array}{l}\text { Not member of } \\
\text { medical scheme }\end{array}$ & 6.566 & .011 & 1.202 & .274 & .217 & .642 & .063 & .803 \\
\hline $\begin{array}{l}\text { Poor subjective } \\
\text { health status }\end{array}$ & 3.596 & .015 & 1.117 & .334 & 1.883 & .134 & 3.340 & .021 \\
\hline $\begin{array}{l}\text { Employment } \\
\text { status }\end{array}$ & 2.214 & .139 & 1.864 & .174 & .394 & .531 & .719 & .398 \\
\hline Sex & 2.519 & .114 & 5.11 & .476 & 1.092 & .297 & .211 & .646 \\
\hline
\end{tabular}

ANOVA significance level 
(A)

\begin{tabular}{|c|c|c|c|c|c|c|c|c|}
\hline \multirow[t]{2}{*}{ Independent variable } & \multicolumn{2}{|c|}{ Availability } & \multicolumn{2}{|c|}{ Accessibility } & \multicolumn{2}{|c|}{ Affordability } & \multicolumn{2}{|c|}{ Acceptability } \\
\hline & $\mathrm{F}$ & $P$ & $\mathrm{~F}$ & $\mathrm{P}$ & $\mathrm{F}$ & $P$ & $\mathrm{~F}$ & $P$ \\
\hline Married & -.113 & .137 & -.070 & .357 & -.151 & .047 & .040 & .598 \\
\hline Formal education & -.131 & .102 & -.009 & .907 & .034 & .672 & .054 & .500 \\
\hline Income & .116 & .405 & .028 & .839 & .163 & .240 & -.015 & .912 \\
\hline Nearest clinic $(\mathrm{km})$ & .089 & .254 & .039 & .618 & -.051 & 512 & -.072 & .354 \\
\hline Nearest doctor $(\mathrm{km})$ & .199 & .011 & .097 & .218 & .091 & .248 & -.018 & .816 \\
\hline Nearest hospital $(\mathrm{km})$ & .142 & .069 & .142 & .069 & -.092 & .239 & .062 & .429 \\
\hline Medical attributes & .081 & .283 & .097 & 218 & .091 & .248 & .068 & .368 \\
\hline Supernatural attributes & -.029 & .699 & .051 & .503 & -.136 & .071 & .025 & .742 \\
\hline Psychosocial attributes & .090 & .232 & .073 & .337 & .096 & .203 & .029 & .699 \\
\hline
\end{tabular}

Pearson Correlation significance level

(B)

\begin{tabular}{|l|l|l|l|}
\hline variables & $\begin{array}{l}\text { There are not enough } \\
\text { family doctors }(G P s) \text { in } \\
\text { our area }\end{array}$ & $\begin{array}{l}\text { People should receive } \\
\text { free hospital treatment }\end{array}$ & $\begin{array}{l}\text { Clinic nurses should } \\
\text { refer their patients for } \\
\text { tests more often }\end{array}$ \\
\hline Age & $.089^{*}(.012)$ & -- & -- \\
\hline $\begin{array}{l}\text { Employment } \\
\text { status }\end{array}$ & -- & $.245(.191)$ & -- \\
\hline $\begin{array}{l}\text { Member of } \\
\text { medical scheme }\end{array}$ & $.103^{*}(.026)$ & $.146(.071)$ & $.139(.079)$ \\
\hline $\begin{array}{l}\text { Poor subjective } \\
\text { health status }\end{array}$ & $.119^{*}(.030)$ & $.209(.138)$ & $.169(.088)$ \\
\hline
\end{tabular}

${ }^{*} p<.05$ : Eta-square significance level in brackets 
Table 3: Health belief questionnaire (Agree=1, sometimes agree=2, disagree $=3$, not sure=4)

\begin{tabular}{|c|c|}
\hline Items & $\mathrm{M}(\mathrm{SD})$ \\
\hline \multicolumn{2}{|l|}{ Medical attributes ( 8 items) } \\
\hline 1. People get sick because they are not strong & $2.36(1.12)$ \\
\hline 4. Illness is caused by infection & $2.15(.97)$ \\
\hline 9. People go to doctors when they are seriously ill & $1.96(1.02)$ \\
\hline 10. Doctors are the only ones who can treat people who are il & $2.31(1.10)$ \\
\hline 13. People inherit illness from their parents & $2.18(.94)$ \\
\hline $\begin{array}{l}\text { 17. Visiting a doctor for regular check ups can prevent a person from } \\
\text { getting sick }\end{array}$ & $1.78(1.01)$ \\
\hline 25. People get sick when something foreign invades their body & $2.44(1.11)$ \\
\hline 28. Sickness occurs because your body is not functioning properly & $2.42(1.06)$ \\
\hline Subtotal & $2.20(1.04)$ \\
\hline \multicolumn{2}{|l|}{ Supernatural attributes (12 items) } \\
\hline 3. Iilness is due to desertion from God & $2.62(1.07)$ \\
\hline 5. Ilness is caused by witchcraft or sorcery & $2.57(1.13)$ \\
\hline $\begin{array}{l}\text { 6. People get sick because someone has cursed or done something evil } \\
\text { towards them }\end{array}$ & $2.42(1.12)$ \\
\hline 8. Sickness 'comes' from the devil & $2.55(1.09)$ \\
\hline 11. There is nothing a person can do to prevent themselves from getting ill & $2.42(1.01)$ \\
\hline 18. Doctors can make the illness better but they cannot treat the cause & $2.28(.99)$ \\
\hline 21. People should pray to God to cure them of their illness & $2.33(1.12)$ \\
\hline $\begin{array}{l}\text { 24. Ilness is a form of punishment for the wrong or bad things a person has } \\
\text { done }\end{array}$ & $2.69(1.01)$ \\
\hline $\begin{array}{l}\text { 26. Sickness occurs because you do not do the rituals or prayers required by } \\
\text { the priest or ancestors }\end{array}$ & $2.40(1.06)$ \\
\hline
\end{tabular}




\begin{tabular}{|l|l|}
\hline $\begin{array}{l}\text { 27. A person can become itl if they walk or cross over the path or spot } \\
\text { where some ritual was performed }\end{array}$ & $2.53(1.07)$ \\
\hline 29. Illness is due to demon, evil or bad spirit possession & $2.85(.92)$ \\
\hline 30. Illness is due to punishment or desertion by the ancestors & $2.97(.99)$ \\
\hline Subtotal & $2.55(1.05)$ \\
\hline Psychosocial attributes (10 items) & \\
\hline 2. People get sick because they do not eat the proper foods & $2.01(.90)$ \\
\hline 7. People get sick because they do not exercise regularly & $2.53(1.01)$ \\
\hline 12. People get sick because they do not keep themselves clean & $2.12(.90)$ \\
\hline 14. If a person takes good care of themselves they will not get sick & $2.38(1.08)$ \\
\hline 15. People are able to cure themselves when they are sick & $2.45(1.00)$ \\
\hline 16. If people get sick it is their own fault & $2.54(1.00)$ \\
\hline 19. Most illnesses can be treated at home & $2.55(.98)$ \\
\hline 20. Older people know a lot about iliness and can advise other what to do & $2.17(1.03)$ \\
\hline 22. People get sick because they are lazy and do not work hard enough & $2.56(1.06)$ \\
\hline 23. When sick the treatment given by elders or older people can really be & $2.18(1.00)$ \\
\hline Subtotal & $2.35(.99)$ \\
\hline
\end{tabular}

Pearson Correlation) with age, gender, marital status, employment status, membership of medical scheme, subjective health status, income, availability, accessibility, affordability and acceptability of biomedical health care, distance to health facilities. No significant differences were however found apart from being single and affordability, nearest doctor and availability of biomedical health care.

\section{DISCUSSION}

This study found a mean distance of $4.8 \mathrm{~km}$ from the consumer's home to the nearest primary health care centre. The normal distance between home and clinic is considered to be between 2-5 km. Vlok (1991: $5 \mathrm{ff}$.) states that The Primary Health Care clinic must be accessible to the community, i.e. it should be within 5 $\mathrm{km}$ of the consumers of health care. The majority of the participants, $71 \%$, stayed beyond $5 \mathrm{~km}$ but at different distances.

In this sample $21 \%$ were members of a medical aid scheme, which is higher than the average of $11.3 \%$ in the Northern Province. In this study a higher insufficiency of family doctors $(84 \%)$ was found than that among the urban Black community in Bloemfontein (66\%) (Van Vuuren and Botes, 1994:3) but the reverse was true for using medical services as they are just available. Regarding accessibility the participants in this study found their health services more accessible than that of the urban Black community (e.g. $43 \%$ felt clinics should be open after business hours as well as opposed to $83 \%$ ). Regarding the other health parameters the participants in this study generally gave similar responses to that of the urban Black community. An exception was that $64 \%$ of the latter agreed their quality of health services is excellent whereas only $13 \%$ of the participants in this study did. This may be explained by the greater accessibility of biomedical health care in the urban as opposed to the rural area.

In terms of acceptability this study shows low rates (e.g. the poor quality of the medical services).

This finding needs further study, especially regarding a further qualification of the perceived low quality of health care. Anyinam (1987:810) has shown that if health services are not acceptable to consumers, they 
will not be utilised even though they might be available and accessible. Acceptability or quality of health care was, in this study, in contrast to other studies not related to socio-economic status (Calnan, 1988:311).

From this study in line with Van Vuuren and Botes (1994:5) it appears that people without health insurance, along with those who consider their personal health to be poor, are of the opinion that health care services are less available (e.g. insufficient family doctors). Increasing age is associated with less availability, which is in contrast with the Bloemfontein study. This may be explained by the fact that in a rural area older people are less mobile to access health care services.

Participants of this study indicated an emphasis on medical health beliefs. This underlines the importance of doctors, especially for prevention and serious illness. In addition, the lack of proper food and hygiene has also been identified as important reasons leading to illness. It is true that the area under study has problems with clean water supply. Differential health beliefs may have a significant relationship with different health providers like traditional healers, faith healers as compared with biomedical health care, and not as found in this study when correlating biographic and attitudes towards biomedical health care with health beliefs attributes (cf. Pillay, 1996:8). Illness attributes were not as expected related to any of the biomedical health services parameters. One would have expected that medical attributes to illness would be related to higher acceptability of biomedical health care than supernatural attributes. In different studies (e.g. Pillay, 1996:4) it was found that people's health beliefs strongly influence their health and illness behaviour.

Limitations of the study are that the sample is restricted to a small geographic area and it was not stratified by age so that the findings cannot be generalised beyond the community and major age group under study. Furthermore, a more comprehensive - on the basis of qualitative research in the community under study taxonomy can be developed to identify the components of quality of health care.

\section{CONCLUSION}

The study found a low acceptability and quality of biomedical health care as perceived by lay persons in a rural South African community. A number of other factors like subjective evaluation of personal health and not being member of a medical scheme, but not illness attributes influenced their attitude towards health services.

The success of strategies to revitalise primary health care services such as those advocated by the Bamako Initiative rests largely on their ability to meet the expectations of population, especially in terms of quality. The evaluation of the quality perceived by the communities thus constitutes an important complement to the evaluations carried out according to the health authorities' own approaches. It is therefore important that primary health care policy makers take cognisance of the existing differences like that of acceptability and affordability in attitudes toward biomedical health care.

The research provides valuable indications about the changes that should be made to promote some areas of the quality of primary health care services. In the area of acceptability the role of interpersonal relations is important. As in other studies, the conduct of the nurses stands out as a central element of the judgement that users make about health services. Health services must take note that their users want proper reception and treatment. Training may allow for the development or improvement of certain technical or even interpersonal skills.

\section{Acknowledgements}

I thank the University of the North for funding the project and Rita Olwagen for the statistical assistance.

\section{REFERENCES}

Anyinam, C 1987: Availability, accessibility, acceptability and adaptability: four attributes of African ethno-medicine. Social Science \& Medicine, $25,1987: 803-811$.

Atkinson, S \& Ngenda, L 1996: Quality of urban health services: Lusaka, Zambia. New York:

UNICEF-Bamako Initiative Operation Research Programme.

Calnan, M 1988: Lay evaluation of medicine and medical practice. International Journal of Health

Services, 18, 1988:311-322.

Craffer, PF 1997: Opposing world-views: the border guards between traditional and biomedical health care practices. South African Journal of Ethnology, 20, 1997:1-8.

Development Bank of Southern Africa 1998: Northern Province: Development Profile 1998. Halfway House, South Africa: Author.

Haddad, S; Fournier, P; Machouf, N \& Yatara, F 1998: What does quality mean to lay people?

Community perceptions of primary health care services in Guinea. Social Science \& Medicine, 47(3), 1998:381-394.

Heap, M \& Ramphele, M 1991: The quest for wholeness: health care strategies among the residents of council-built hostels in Cape Town. Social Science \& Medicine, 32, 1991:117-126. 
Hildebrandt, E 1997: Have I angered my ancestors? Influences of culture on health care with elderly black South Africans as an example. Journal of Multicultural Nursing and Health, 3, 1997:40-49.

Miralles, MA \& Kimberlin, CL 1998: Perceived access to care and medication use among ambulatory elderly in Rio de Janeiro, Brazil. Social Science \& Medicine, 46, 1998:345-355.

Pillay, BJ 1996: A model of help-seeking behaviour for urban blacks. South African Journal of

Psychology, 26, 1996:4-9.

Thipanyana, M \& Mavundla, TR 1998: The provision of primary health care in two rural districts of the Eastern Cape Province with particular reference to human resources and accessibility. Curationis, 21, 1998:26-31.
Van Vuuren, SJEJ \& Botes, LJS 1994: Attitudes towards health care in greater Bloemfontein. Curationis, 17, 1994:2-10.

Vlok, ME 1991: Manual of community nursing and communicable diseases. Kenwyn: Juta.

\title{
BOOK REVIEW
}

\section{GETTING THE LOVE YOU WANT. A GUIDE FOR COUPLES}

\author{
Harville Hendrix \\ Simon \& Schuster of Australia Pty Ltd. Sydney
}

Dr Harville Hendrix is one of the world's leading marital therapists. He began his career as a therapist counselling both individuals and couples. He mentioned that he felt competent and effective with individuals, but saw the marital relationship as a complex system and he was not always capable of dealing with couples effectively. He ended up doing what most therapists did: problem-orientated contractual marriage counselling. This approach was not always useful or effective. His interest in relationship therapy started out of his own despair and disappointment after his divorce, and he had a compelling desire to make sense out of his dilemma.

He did intensive research through professional books and joumals, but couldn't find any meaningful discussions of marriage, or no comprehensive theory to explain the intricacies of the male/female relationship. To fill this gap he worked with hundreds of couples in private practice and thousands more in workshops and seminars.

Out of this research and marital therapy he developed a theory of marital therapy called Imago Relationship Therapy. The approach was electric. The divorce rate in his practice declined and the couples who stayed together reported a much deeper satisfaction in their marriages.

This book is about the theory and practice of becoming passionate friends. The book is divided into three parts. Part 1 focuses on "the unconscious marriage", an emerging psychological drama, that reveals all the hidden desires and automatic behaviours that are left over from childhood and form a leading source in creating marital conflict.

Part 2 explores the "conscious marriage" and helps you to satisfy your unmet childhood needs in positive ways.

Part 3 takes on all the ideas in Part $1 \& 2$, compiled into a unique ten week step by step course in relationship therapy.

This book can be very valuable to all advanced psychiatric nurse practitioners in the field in facilitating a more loving and supportive relationship in couples to promote their mental health.

Sandra van Wyk, RN, DCur Lecturer, Department of Nursing Science, Rand Afrikaans University 